\title{
Adsorption isotherms and kinetics pertinent to modified composite hydrogel adsorbents adopted for heavy metals removal
}

\author{
Mohamed H. Sorour, Heba A. Hani*, Hayam F. Shaalan, Marwa M. \\ El Sayed, Mahmoud A. El-Toukhy \\ Chemical Engineering and Pilot Plant Department, National Research Centre, Giza, \\ Egypt
}

\begin{abstract}
Environmental friendly adsorbents constitute an effective method for heavy metals pollution mitigation. In this work, batch adsorption experiments were conducted for the adsorption of various heavy metals including $\mathrm{Cr}, \mathrm{Co}, \mathrm{Ni}$ and $\mathrm{Pb}$ using cost-effective modified adsorbents. These comprise polyacrylate hydrogels prepared using microwave (M) irradiation technique (ACM) or ultrasonic (U) irradiation technique (ACU). Further blends of acrylic acid salts with Egyptian kaolin (AKM and AKU) or zeolite (AZM and $\mathrm{AZU})$ were also investigated. The effect of $\mathrm{pH}$ and initial concentration on the performance of the composite hydrogels has been studied. Also, several adsorption isotherm and kinetic models were studied. AKU revealed the highest maximum adsorption capacities among other investigated composites for all the tested heavy metals. The equilibrium adsorption experiments revealed that Langmuir isotherm model is best fitted than other models with maximum adsorption capacities of 84.5, 73.3, 61 and 97 $\mathrm{mg} / \mathrm{g}$ for $\mathrm{Cr}, \mathrm{Co}, \mathrm{Ni}$ and $\mathrm{Pb}$, respectively and equivalent results were obtained from Tempkin isotherm for all ions except $\mathrm{Ni}$. Adsorption kinetics of $\mathrm{Cr}, \mathrm{Co}, \mathrm{Ni}$ and $\mathrm{Pb}$ using all the composite hydrogels were best described with the Pseudo-second order kinetic model.
\end{abstract}

Keywords: Heavy metals, Cost-effective, Composites, Adsorption isotherm, Kinetics.

Received: January 13, 2021

Revised: May 23, 2021

Accepted: May 25, 2021

Corresponding Author:

Heba A. Hani

ha.hani@nrc.sci.eg

Copyright: The Author(s). This is an open access article distributed under the terms of the Creative Commons Attribution License (CC BY 4.0), which permits unrestricted distribution provided the original author and source are cited.

\section{Publisher:}

Chaoyang University of

Technology

ISSN: 1727-2394 (Print)

ISSN: 1727-7841 (Online)

\section{INTRODUCTION}

Heavy metals pollution is receiving increasing endeavors from the research community in recognition of its documented serious effects on health and the environment. Current practices for the removal of hazardous heavy metals comprise adsorption, precipitation, coagulation, ion exchange and membrane techniques (Barakat, 2011; Emamjomeh and Sivakumar, 2009; Esalah et al., 1999; Ghurye et al., 2004; Mahmoud and Hoadley, 2012; Yurlova et al., 2002). Adsorption technology is one of the cornerstones for alleviating heavy metal pollution episodes (Barakat, 2011; Renu and Singh, 2017). Further, some situations dictate the siting of the adsorption unit upstream or downstream of the treatment line. Numerous endeavors for improving the performance and stability of adsorbents comprise, but not limited to, enhancing the effectiveness of current commercial adsorbents, developing new promising organicinorganic hybrid polymers (Bhatia et al., 2017; Inagaki et al., 2007; Liu et al., 2012; Zhao et al., 2010). Ecofriendly green adsorbents based on modified natural polymers and their composites are now the focus of numerous research groups around the world. These green adsorbents comprise for example chitosan, cellulose ones, alginates (Gomez-Maldonado et al., 2019). Modified clays and zeolite adsorbents are also used in current practices (Renu and Singh, 2017). One of the materials that is gaining wide acceptance is hydrogel which has numerous advantages for heavy metals removal. These 
include hydrophilicity, dimensional stability, minimum toxicity, the multiplicity of functional groups that could be attached to the base polymer and biodegradability which facilitates final disposal of exhausted adsorbates (Elsayed, 2019; Sezgin and Balkaya, 2016). The performance of clay/hydrogel composites for hardness and heavy metals removal from their solutions have been studied by several authors (Bulut et al., 2009; Liu et al., 2015; Natkański et al., 2012; Sorour et al., 2018; Sorour et al., 2020). For instance, lead removal by polyacrylic acid-organo-bentonite nanocomposite, polyacrylic acid hydrogel beads and sodium polyacrylate-bentonite material approached $93 \mathrm{mg} / \mathrm{g}$ (Rafiei et al., 2016), $113 \mathrm{mg} / \mathrm{g}$ (Al-Abachi, 2013), and $70 \mathrm{mg} / \mathrm{g}$ (He et al., 2016a). Moreover, $\mathrm{Cu}, \mathrm{Zn}, \mathrm{Cd}$ and $\mathrm{Mn}$ were successfully removed by sodium polyacrylatehumic acid rectorite composite (Chen et al., 2012) and kaolinite containing polyacrylic acid-co-acrylamide hydrogels (Atia et al., 2009). Besides, polysaccharidezeolite, zeolite acrylamide maleic-acid and chitosan-zeolite $\mathrm{Na}-\mathrm{X}$ based composites have been studied for the removal of $\mathrm{Cu}, \mathrm{Cd}, \mathrm{Pb}$ and $\mathrm{Zn}$ (Akkaya and Ulusoy, 2011; Djelad et al., 2016; Zhang and Wang, 2015).

With such increasing interest and practice of green adsorbents, it deemed necessary to investigate the applicable isotherm and pertinent kinetic models to a newly developed cost-effective composite hydrogel incorporating tailored blending of kaolin or zeolite to microwave/ultrasonic processed polyacrylate hydrogels.

This work investigates the adsorption performance of the previously prepared polyacrylate coated kaolin/zeolite composite hydrogels for the removal of $\mathrm{Cr}, \mathrm{Co}, \mathrm{Ni}$ and $\mathrm{Pb}$ from their synthetic solutions. In addition, the adsorption isotherm models and kinetic study were thoroughly investigated and compared.

\section{MATERIALS AND METHODS}

\subsection{Materials}

In house prepared hydrogel composite samples reported by the authors (Sorour et al., 2018; Sorour et al., 2020), were used as cost-effective adsorbents in this study. These comprise polyacrylate hydrogels prepared using microwave (M) irradiation technique (ACM) or ultrasonic (U) irradiation technique (ACU). Further, blends of acrylic acid and Egyptian kaolin (AKM and AKU) or zeolite (AZM and AZU) were also investigated. Investigated heavy metal ions include $\mathrm{Cr}, \mathrm{Co}, \mathrm{Ni}$ and $\mathrm{Pb}$ and their salts were used for the preparation of synthetic solutions. $\mathrm{CoCl}_{2}$ (Shantou Guanghua Chemical Factory Co., Ltd), $\mathrm{Cr}\left(\mathrm{NO}_{3}\right)_{3} \cdot 6 \mathrm{H}_{2} \mathrm{O}$ (PRS Panareac Quimica Sa), $\mathrm{NiCl}_{2} \cdot 6 \mathrm{H}_{2} \mathrm{O}$ (S.d.fine-chem Ltd.) and $\mathrm{Pb}\left(\mathrm{CH}_{3} \mathrm{COO}\right)_{2} \cdot 3 \mathrm{H}_{2} \mathrm{O}$ were used. Hydrochloric acid and sodium carbonate were used for $\mathrm{pH}$ adjustment.

\subsection{Adsorption Studies}

Adsorption experiments were conducted using the batchmode technique with $\mathrm{pH}$ variation (4-8.5) (Dean et al., 1972) as measured by a $\mathrm{pH}$ meter (HANNA apparatus model-211). All the samples mentioned in section 2.1 were investigated and their particle size was below $850 \mu \mathrm{m}$. They were added to the prepared heavy metal ions containing single system solutions in appropriate flasks. The flasks were sealed and constantly shaken using a water bath shaker (Julabo, SW20C) with constant stirring $(150 \mathrm{rpm})$ at $27^{\circ} \mathrm{C}$. Adsorption was performed for $\mathrm{Cr} \mathrm{Co}, \mathrm{Ni}$ and $\mathrm{Pb}$ in their synthetic solutions at initial concentration $\left(\mathrm{C}_{\mathrm{i}}\right)$ 10-100 mg/L. Adsorption time ranged from $10 \mathrm{~min}$ up to $24 \mathrm{~h}$. The supernatant was separated by filtration technique using a Whatman filter paper no. 4 and analyzed to determine the concentration of the residual elements in solution.

Concentrations of ions before and after treatment were measured using an atomic absorption flame spectrometer (GBC, Avanta). The adsorption capacity (q) was calculated using the following equation (Green, 2008; Hani, 2010):

$q=\frac{C_{i}-C_{e}}{m} \times V$

Where, $\mathrm{q}$ is the amount of metal ions adsorbed in $(\mathrm{mg} / \mathrm{g}$ of dry adsorbent), $\mathrm{C}_{\mathrm{i}}$ and $\mathrm{C}_{\mathrm{e}}$ are the initial and equilibrium ion concentrations $(\mathrm{mg} / \mathrm{L})$, respectively; $\mathrm{V}$ is the volume of metal ions solution used (L), and $\mathrm{m}$ is the weight of dry adsorbent (g).

\subsection{Adsorption Isotherm Models}

Several equilibrium models were investigated including Langmuir, Freundlich, Dubinin-Radushkevich, Tempkin and Florry-Huggins isotherms (Ayawei et al., 2017; Foo and Hameed, 2010; Nechifor et al., 2015; Shikuku et al., 2018). Langmuir isotherm assumes monolayer adsorption using a surface with a finite number of identical sites, Freundlich isotherm; interprets the adsorption on heterogeneous surfaces with interactions occurring between the adsorbed molecules and is not restricted to the formation of a monolayer. Moreover, Dubinin-Radushkevich (D-R) isotherm assumes that the adsorption has a multilayer character and involves Vander Waals forces. While Tempkin and Florry-Huggins isotherms evaluate the adsorption potential of the adsorbent and adsorbate. Table 1 summarizes each of the pre-mentioned models with their parameters.

For the quick prediction of isotherm profile, a tailored software has been developed, tested and evaluated using Visual Basic (version 10) software and used for fitting and parameters estimation of all isotherm models.

\subsection{Kinetic Study of the Adsorption Process}

The kinetic models of sorption that define the adsorption rate, mechanism and optimum sorption time are investigated. These include Pseudo first and second order and Elovich kinetic models (Qiu et al., 2009; Wang and Guo, 2020; Yakout and Elsherif, 2010). The Pseudo-first-order model is the most widely used rate equation in liquid phase sorption. It assumes that the rate of change of sorbate uptake with time is directly proportional to the difference in the saturation concentration and the amount of solid uptake 


\section{International Journal of Applied Science and Engineering}

Sorour et al., International Journal of Applied Science and Engineering, 18(5), 2021013

Table 1. Summary of investigated adsorption isotherm and kinetic models

\begin{tabular}{|c|c|c|c|c|c|}
\hline Model & Nonlinear form & Linear form & Plot & Constants & Ref. \\
\hline & & $\frac{1}{q_{e}}=\frac{1}{b * q_{m}}+\frac{C_{e}}{q_{m}}$ & $\frac{1}{\mathrm{q}_{\mathrm{e}}}$ vs. $\frac{1}{\mathrm{C}_{\mathrm{e}}}$ & $\mathrm{b}, \mathrm{q}_{\mathrm{m}}$ & \multirow{2}{*}{$\begin{array}{l}\text { Ayawei et al. } \\
\text { (2017); Foo and } \\
\text { Hameed (2010); } \\
\text { Shikuku et al. } \\
\text { (2018) }\end{array}$} \\
\hline Langmuir & $\begin{array}{l}=\mathrm{q}_{\mathrm{b}} * \mathrm{C}_{\mathrm{e}} \\
+\frac{\mathrm{b} * \mathrm{C}_{\mathrm{e}}}{1+{ }^{2}}\end{array}$ & $\begin{array}{l}\frac{\mathrm{C}_{\mathrm{e}}}{\mathrm{q}_{\mathrm{e}}} \\
=\frac{1}{\mathrm{q}_{\mathrm{m}}}+\frac{1}{\mathrm{C}_{\mathrm{e}} * \mathrm{~b} * \mathrm{q}_{\mathrm{m}}}\end{array}$ & $\frac{\mathrm{C}_{\mathrm{e}}}{\mathrm{q}_{\mathrm{e}}}$ vs. $\mathrm{C}_{\mathrm{e}}$ & $\mathrm{b}, \mathrm{q}_{\mathrm{m}}$ & \\
\hline Freundlich & $\mathrm{q}_{\mathrm{e}}=\mathrm{K}_{\mathrm{F}} * \mathrm{C}_{\mathrm{e}}^{1 / \mathrm{n}}$ & $\begin{array}{l}\log \mathrm{q}_{\mathrm{e}} \\
=\log \mathrm{K}_{\mathrm{F}}+\frac{1}{\mathrm{n}} \log \mathrm{C}_{\mathrm{e}}\end{array}$ & $\log q_{e} v s \cdot \log C_{e}$ & $\mathrm{~K}_{\mathrm{F}}, \mathrm{n}$ & $\begin{array}{c}\text { Ayawei et al. } \\
\text { (2017); Foo and } \\
\text { Hameed (2010); } \\
\text { Shikuku et al. } \\
\text { (2018) }\end{array}$ \\
\hline $\begin{array}{l}\text { Dubinin- } \\
\text { Radushkevich } \\
\text { (D-R) }\end{array}$ & $\begin{array}{l}\mathrm{q}_{\mathrm{e}} \\
=\mathrm{q}_{\mathrm{s}} \\
* \exp \left(\mathrm{K}_{\mathrm{ad}} * \zeta^{2}\right)\end{array}$ & $\begin{array}{l}\ln \left(\mathrm{q}_{\mathrm{e}}\right) \\
=\ln \left(\mathrm{q}_{\mathrm{s}}\right)-\left(\mathrm{K}_{\mathrm{ad}}\right. \\
\left.* \zeta^{2}\right)\end{array}$ & $\ln \left(q_{e}\right) \mathrm{vs} . \zeta^{2}$ & $\begin{array}{l}\varepsilon_{\mathrm{ad}}, \mathrm{E} \\
=\mathrm{RT} \\
* \ln \left(1+\frac{1}{\mathrm{C}_{\mathrm{e}}}\right) \\
\mathrm{E}=\frac{1}{\sqrt{2 * \mathrm{~K}_{\mathrm{ad}}}}\end{array}$ & $\begin{array}{l}\text { Ayawei et al., } \\
\text { (2017); Foo and } \\
\text { Hameed (2010) }\end{array}$ \\
\hline Tempkin & $\begin{array}{l}\mathrm{q}_{\mathrm{e}} \\
=\frac{\mathrm{R} * \mathrm{~T}}{\mathrm{~b}_{T}} * \ln \left(\mathrm{A}_{T}\right. \\
\left.* \mathrm{C}_{\mathrm{e}}\right)\end{array}$ & $\begin{array}{l}\mathrm{q}_{e} \\
=\frac{R * T}{b_{T}} \ln \left(\mathrm{A}_{T}\right) \\
+\frac{\mathrm{R} * \mathrm{~T}}{b_{T}} \ln \left(\mathrm{C}_{\mathrm{e}}\right)\end{array}$ & $\mathrm{q}_{e} \mathrm{vs} \cdot \ln \left(\mathrm{C}_{\mathrm{e}}\right)$ & $\mathrm{b}_{\mathrm{T}}, \mathrm{A}_{\mathrm{T}}$ & $\begin{array}{l}\text { Ayawei et al. } \\
\text { (2017); Foo and } \\
\text { Hameed (2010); } \\
\text { Nechifor et al. } \\
\text { (2015); Shikuku } \\
\text { et al. (2018) }\end{array}$ \\
\hline Florry-Huggins & $\begin{array}{l}\frac{\theta}{\mathrm{C}_{\mathrm{i}}} \\
=\mathrm{K}_{\mathrm{FH}} \\
*(1-\theta)^{\mathrm{n}_{\mathrm{FH}}}\end{array}$ & $\begin{array}{l}\log \frac{\theta}{C_{i}} \\
=\log \mathrm{K}_{\mathrm{FH}}+n_{F H} \log (1 \\
-\theta)\end{array}$ & $\begin{array}{l}\log \frac{\theta}{C_{i}} \text { vs. } \log (1 \\
-\theta)\end{array}$ & $\begin{array}{l}\mathrm{K}_{\mathrm{FH}}, \mathrm{n}_{\mathrm{FH}}, \Delta \mathrm{G} \\
\quad \Delta \mathrm{G} \\
\quad=-\mathrm{RT} \\
\quad * \ln \left(K_{F H}\right)\end{array}$ & $\begin{array}{c}\text { Ayawei et al. } \\
\text { (2017); Foo and } \\
\text { Hameed (2010); } \\
\text { Nechifor et al. } \\
\text { (2015) }\end{array}$ \\
\hline
\end{tabular}

Table 2. Summary of investigated adsorption kinetic models

\begin{tabular}{|c|c|c|c|c|c|}
\hline Model & Nonlinear form & Linear form & Plot & Constants & Ref. \\
\hline Pseudo-first-order & $\begin{array}{l}\frac{\mathrm{dq}_{\mathrm{t}}}{\mathrm{dt}} \\
=\mathrm{k}_{1} *\left(\mathrm{q}_{\mathrm{e}}\right. \\
\left.-\mathrm{q}_{\mathrm{t}}\right)\end{array}$ & $\begin{array}{l}\log \left(\mathrm{q}_{\mathrm{e}}-\mathrm{q}_{\mathrm{t}}\right) \\
=\log \left(\mathrm{q}_{\mathrm{e}}\right)-\frac{\mathrm{k}_{1}}{2.303} * \mathrm{t}\end{array}$ & $\underset{t}{\log \left(\mathrm{q}_{\mathrm{e}}-\mathrm{q}_{\mathrm{t}}\right) \mathrm{vs}}$ & $\mathrm{k}_{1}$ & $\begin{array}{c}\text { (Qiu et al., 2009; Wang } \\
\text { and Guo, 2020; Yakout } \\
\text { and Elsherif, 2010) }\end{array}$ \\
\hline Pseudo-second-order & $\begin{array}{l}\frac{\mathrm{dq}}{\mathrm{dt}}=\mathrm{k}_{2} * \\
\left(\mathrm{q}_{\mathrm{e}}-\mathrm{q}_{\mathrm{t}}\right)^{2}\end{array}$ & $\frac{\mathrm{t}}{\mathrm{q}_{\mathrm{t}}}=\frac{1}{\mathrm{k}_{2}} * \frac{1}{\mathrm{q}_{\mathrm{e}}^{2}}+\frac{1}{\mathrm{q}_{\mathrm{e}}} * \mathrm{t}$ & $\frac{t}{q_{t}}$ vs.t & $\mathrm{k}_{2}$ & $\begin{array}{c}\text { (Qiu et al., 2009; Wang } \\
\text { and Guo, 2020; Yakout } \\
\text { and Elsherif, 2010) }\end{array}$ \\
\hline Elovich & $\frac{\mathrm{dq}_{\mathrm{t}}}{\mathrm{dt}}=\mathrm{a}_{\mathrm{e}} * \mathrm{e}^{\frac{-\mathrm{qt}}{\mathrm{be}}}$ & $\begin{array}{l}q_{t} \\
=\frac{\ln a_{e} b_{e}}{b_{e}}+\frac{1}{b_{e}} \ln t\end{array}$ & $\mathrm{q}_{\mathrm{t}} \mathrm{vs} \cdot \ln \mathrm{t}$ & $a_{e}, b_{e}$ & $\begin{array}{c}\text { (Qiu et al., 2009; Wang } \\
\text { and Guo, 2020; Yakout } \\
\text { and Elsherif, 2010) }\end{array}$ \\
\hline
\end{tabular}

with time. The Pseudo-second-order model describes a second-order rate of sorption, while Elovich's equation is also used successfully to describe second-order kinetics of the chemisorption process assuming that the actual solid surfaces are energetically heterogeneous. Table 2 summarizes investigated kinetic models in this study. Excel software was used for fitting and parameters estimation of kinetic models.

\section{RESULTS AND DISCUSSION}

3.1 Adsorption Performance of hydrogel composites

Fig. 1 represents the adsorption capacities of different heavy metals at $\mathrm{pH} 4$ and an initial concentration of $10 \mathrm{mg} / \mathrm{L}$ using the investigated adsorbents. It is deduced from Fig. 1 that the inclusion of kaolin and zeolite into the polyacrylate hydrogel structure enhanced $\mathrm{Cr}$ uptake especially for 


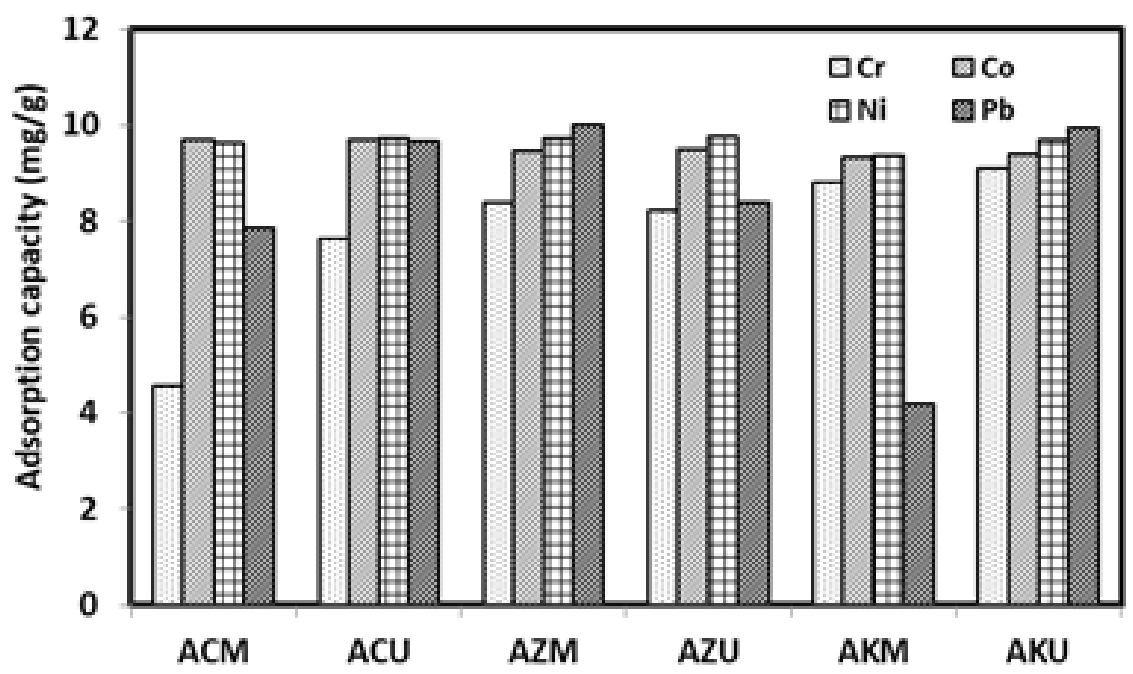

Fig. 1. Adsorption capacities of the composite hydrogels for different heavy metals $\left(\mathrm{C}_{\mathrm{i}} 10 \mathrm{mg} / \mathrm{L}, \mathrm{pH} 4\right)$

microwave prepared hydrogel samples (by more than $80 \%$ ) while; Co and Ni uptake was slightly increased after kaolin and zeolite addition. Moreover, $\mathrm{Pb}$ uptake increased for microwave and ultrasonic prepared samples using zeolite $(27 \%)$ and kaolin $(3 \%)$, respectively.

\subsubsection{Effect of $\mathrm{pH}$ on adsorption}

The $\mathrm{pH}$ dependence of adsorption from 4 to 8 is typically shown in Fig. 2. By increasing $\mathrm{pH}$ from 4 to 8 the adsorption differs which may be explained by the existence of the metal ions as different complexes in aqueous solutions at different $\mathrm{pH}$ values and the behavior of each will be different. Moreover, charges on the adsorbent itself vary according to $\mathrm{pH}$ and consequently, its adsorption behavior is different, which agrees with Wan Ngah et al. (2011). It is also clear from Fig. 2 that for the tested ions within the investigated $\mathrm{pH}$ range, AKU and AZM attained higher performance as compared to AKM and AZU, respectively. Moreover, AKU and AZM revealed comparable performance at this concentration at certain $\mathrm{pH}$ values where the performance of AKU is slightly higher for most of the ions as shown in Table 3. Accordingly, AKU and AZM were selected for subsequent adsorption studies at selected $\mathrm{pH}$ values.

\subsubsection{Effect of Metal Concentration on Adsorption}

The effect of metal ion concentration (10-100 mg/L) on adsorption is depicted in Fig. 3 using the most appropriate adsorbent and $\mathrm{pH}$ (depicted from the previous section), where average experimental values are represented (solid lines manifest adsorption capacities and dotted lines manifest removal efficiencies). The removal efficiency decreases with increasing initial metal concentration while the adsorption capacity increased. At low initial concentrations, the removal was higher due to the larger surface area and vacant sites of the composite adsorbent. At higher initial concentration, the ratio of the initial number of ions to the available sites was higher and as a result, the removal decreased which agrees with Hani (2010) and Liu et al., (2015). At the maximum studied metal concentrations (86-100 mg/L), AKU attained the highest loading rates (70, 71,78 and $93 \mathrm{mg} / \mathrm{g}$ ) and removal efficiencies (92, 78, 92 and $93 \%$ ) for $\mathrm{Cr}$, $\mathrm{Co}$ and $\mathrm{Pb}$ while maximum attained adsorption capacity for $\mathrm{Ni}$ was $(78 \mathrm{mg} / \mathrm{g})$ at an initial concentration of $85.7 \mathrm{mg} / \mathrm{L}$. Regarding AZM, the maximum adsorption capacities for $\mathrm{Cr}$, $\mathrm{Co}, \mathrm{Ni}$ and $\mathrm{Pb}$ were 46, 46, 74 and $96 \mathrm{mg} / \mathrm{g}$ respectively, with corresponding removal efficiencies of $78,79,86$ and $96 \%$ at metal concentrations range $58.5-100 \mathrm{mg} / \mathrm{L}$.

Table 3. Highest performance of selected kaolin/zeolite composite polyacrylate hydrogels at different $\mathrm{pH}$ values

\begin{tabular}{|c|c|c|c|c|c|c|c|c|}
\hline \multirow[b]{3}{*}{ Composite hydrogel } & \multicolumn{6}{|c|}{$\left(\mathrm{C}_{\mathrm{i}}=10 \mathrm{mg} / \mathrm{L}\right)$} & \multirow{2}{*}{\multicolumn{2}{|c|}{$\mathrm{Pb}$}} \\
\hline & $\mathrm{C}$ & & $\mathrm{Cc}$ & & $\mathrm{N}$ & & & \\
\hline & $\begin{array}{l}\text { Uptake } \\
\text { (mg/g) }\end{array}$ & $\mathrm{pH}$ & $\begin{array}{l}\text { Uptake } \\
\text { (mg/g) }\end{array}$ & $\mathrm{pH}$ & $\begin{array}{l}\text { Uptake } \\
\text { (mg/g) }\end{array}$ & $\mathrm{pH}$ & $\begin{array}{l}\text { Uptake } \\
\text { (mg/g) }\end{array}$ & $\mathrm{pH}$ \\
\hline AKU & 9.1 & 5.4 & 9.77 & 7 & 9.68 & 6 & 9.93 & 4 \\
\hline AZM & 8.6 & 5 & 9.83 & 6 & 9.64 & 6 & 10 & 5 \\
\hline
\end{tabular}




\section{International Journal of Applied Science and Engineering}

Sorour et al., International Journal of Applied Science and Engineering, 18(5), 2021013

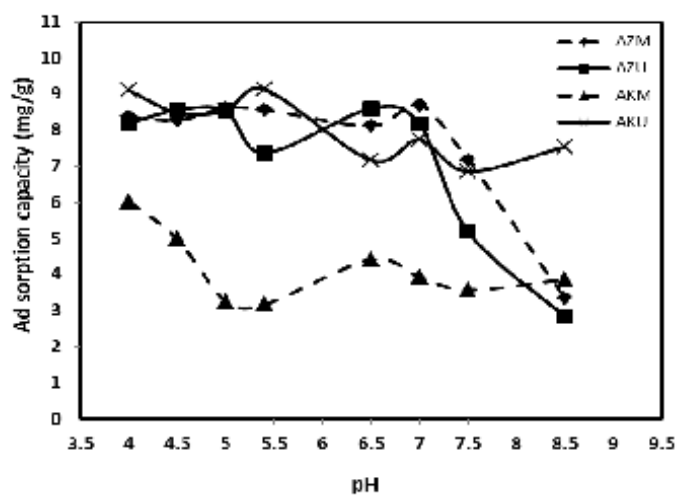

a) $\mathrm{Cr}$

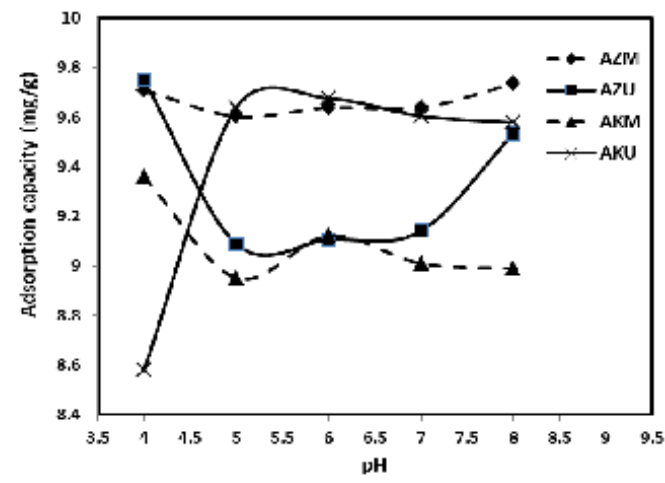

c) $\mathrm{Ni}$

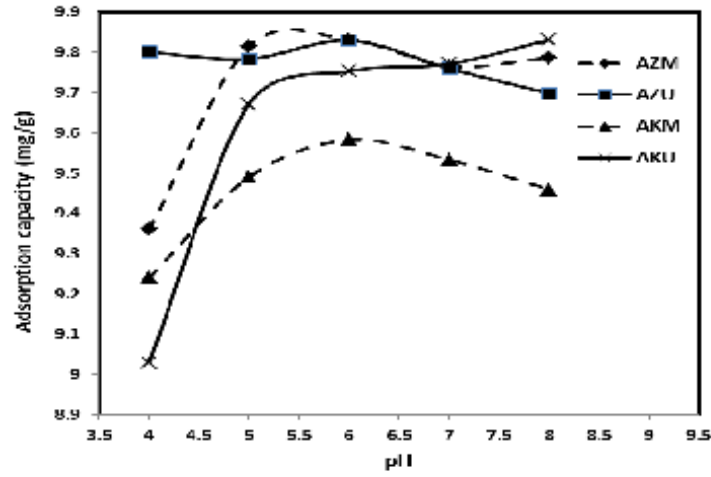

b) Co

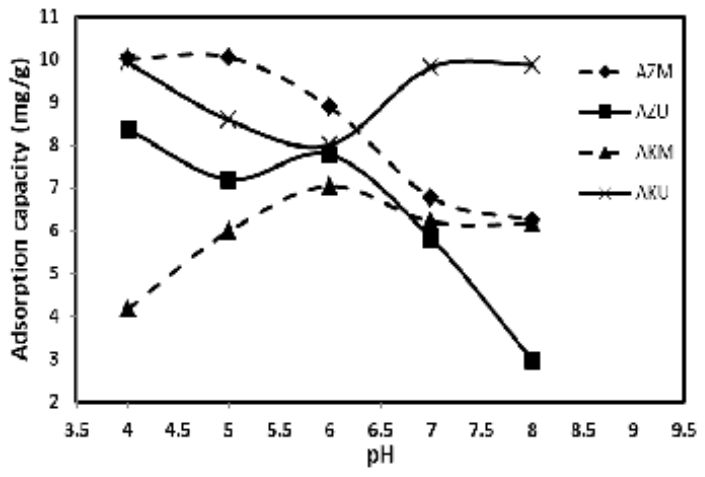

d) $\mathbf{P b}$

Fig. 2. $\mathrm{pH}$ dependence of heavy metals adsorption $\left(\mathrm{C}_{\mathrm{i}} 10 \mathrm{mg} / \mathrm{L}\right)$

\subsection{Adsorption Isotherm Studies}

Adsorption data of $\mathrm{Cr}, \mathrm{Co}, \mathrm{Ni}$ and $\mathrm{Pb}$ using $\mathrm{AKU}$ and AZM were analyzed using Langmuir, Freundlich, DubininRadushkevich, Tempkin and Florry (as mentioned in section
2.3). Thus, adsorption isotherm plots and fittings as obtained from the developed software using Visual Basic are shown in Fig. 4. The coefficients for the linearized forms of the isotherms and correlation coefficients at optimum $\mathrm{pH}$ and concentrations are presented in Table 4 . 


\section{International Journal of Applied Science and Engineering}

Sorour et al., International Journal of Applied Science and Engineering, 18(5), 2021013

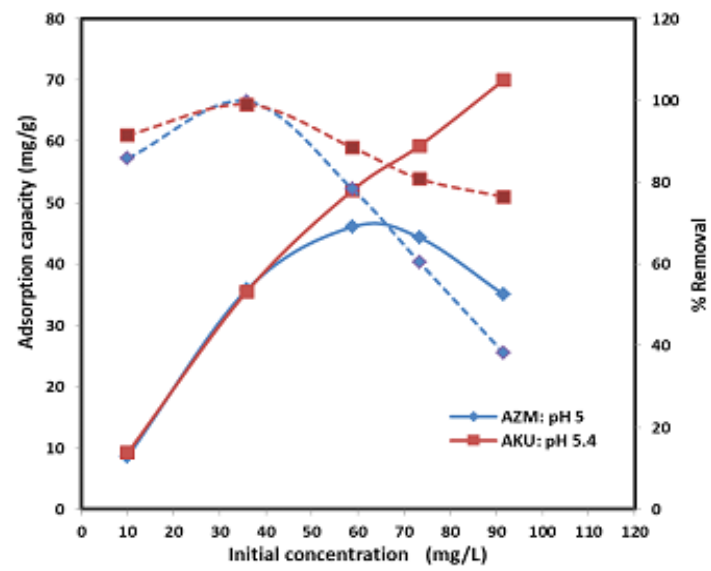

a) $\mathrm{Cr}$

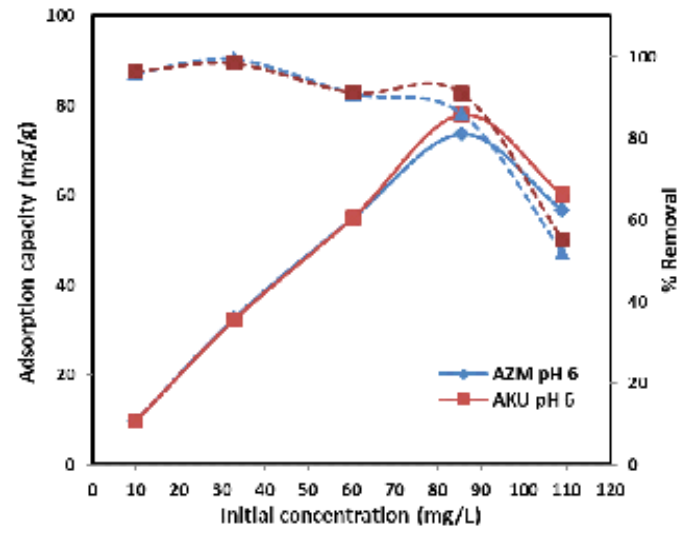

c) $\mathrm{Ni}$

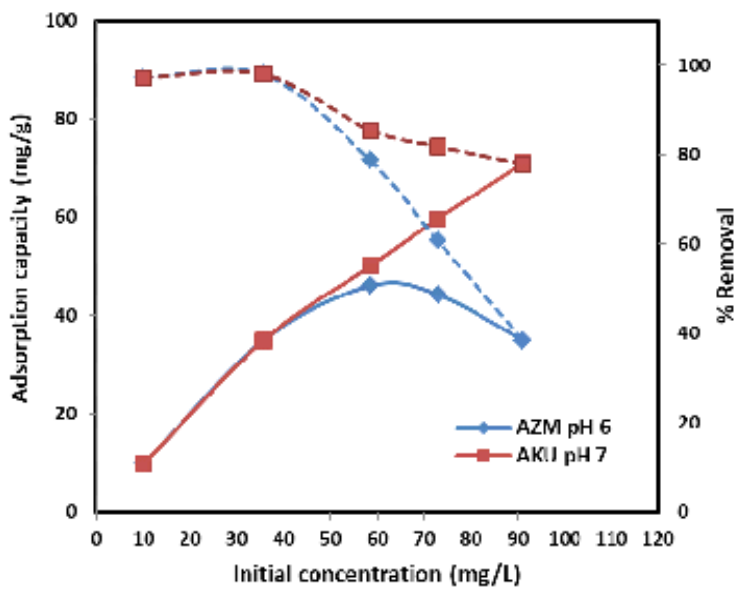

b) Co

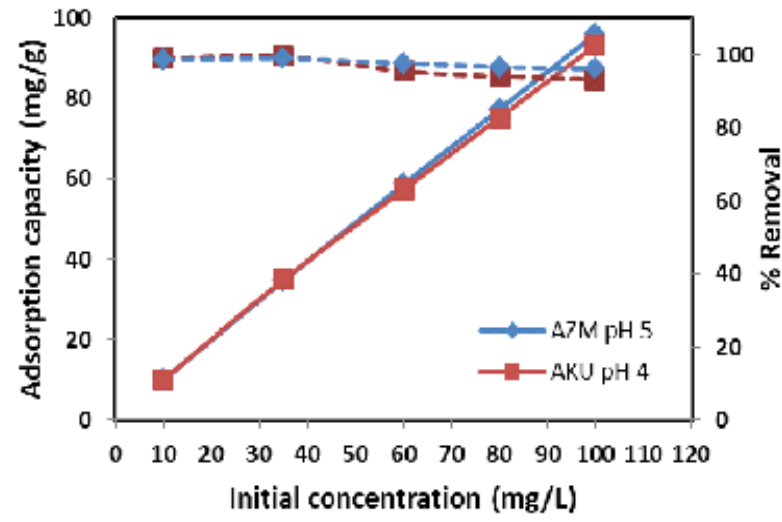

d) $\mathrm{Pb}$

Fig. 3. Effect of heavy metal concentration on adsorption capacities and \% removal at specified $\mathrm{pH}$ values. Solid lines: adsorption capacities, dotted lines: removal efficiencies

Analysis of the correlation coefficients in Table 4 shows that Langmuir isotherm is adequate to describe the adsorption data of $\mathrm{Cr}, \mathrm{Co}, \mathrm{Ni}$ and $\mathrm{Pb}$ for $\mathrm{AKU}$ and $\mathrm{AZM}$. It is worth mentioning that Tempkin isotherm competes with Langmuir for $\mathrm{Cr}, \mathrm{Co}$ and $\mathrm{Pb}$ using $\mathrm{AKU}$ composite. For $\mathrm{Pb}$ ions sorption using AZM, the Langmuir model shows comparable fittings (correlation coefficient 0.974) with Dubinin-Radushkevich (D-R) (0.947) and Tempkin isotherm (0.98), which is considered the highest. Calculation of adsorption energy (E) using the D-R isotherm model could be calculated only for $\mathrm{Pb}$ on AZM as it fits with the $\mathrm{D}-\mathrm{R}$ isotherm. Thus, the calculated value of $\mathrm{E}$ for $\mathrm{Pb}$ is $10.9 \mathrm{~kJ} / \mathrm{mol}$ which lies in the typical range of bonding energy for ion-exchange mechanisms is $8-16 \mathrm{~kJ} / \mathrm{mol}$ (ElKamash et al., 2005; Hani, 2010). Thus, given the comparable values for the investigated isotherms, the Langmuir model (mostly the second form, as mentioned in Table 4) could be used safely for data analysis.

As shown in Table 4, $\mathrm{q}_{\mathrm{m}}$ which is indicative of maximum adsorption capacities as depicted from Langmuir isotherm, are $97.2,84.5,73.3$ and $60.9 \mathrm{mg} / \mathrm{g}$, in the order of selectivity $\mathrm{Pb}>\mathrm{Cr}>\mathrm{Co}>\mathrm{Ni}$, respectively using the composite AKU. It is also worth mentioning that AZM revealed higher maximum adsorption capacity only for $\mathrm{Pb}$ as depicted from Langmuir isotherm $(128 \mathrm{mg} / \mathrm{g})$ as shown in Table 4. 


\section{International Journal of Applied Science and Engineering}

Sorour et al., International Journal of Applied Science and Engineering, 18(5), 2021013

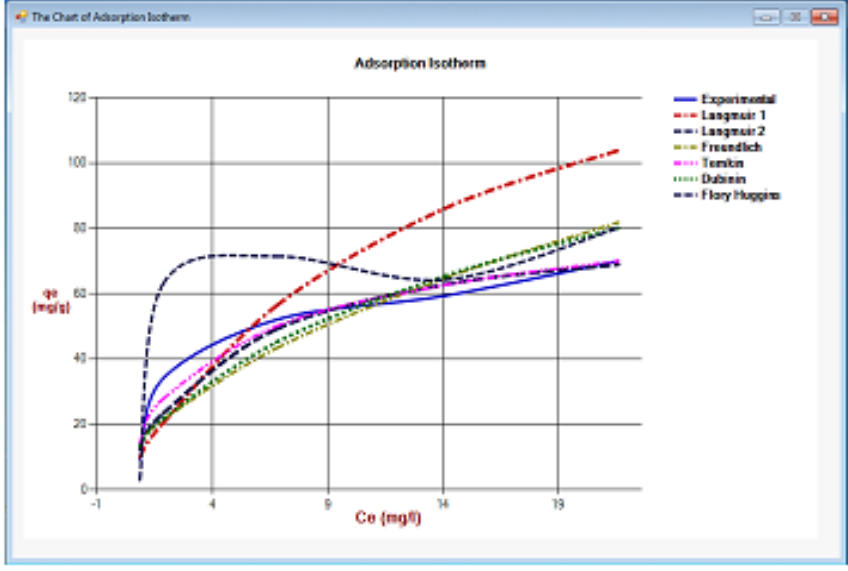

AKU

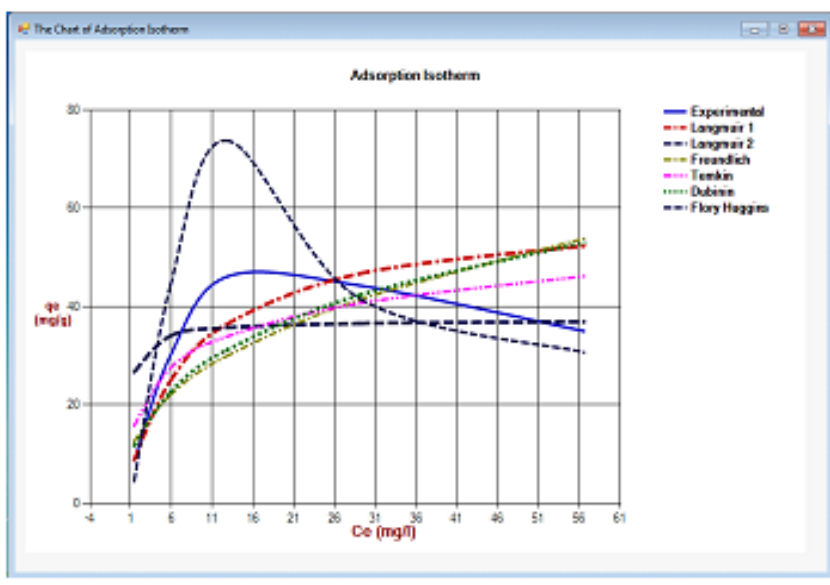

AZM

a) $\mathrm{Cr}$

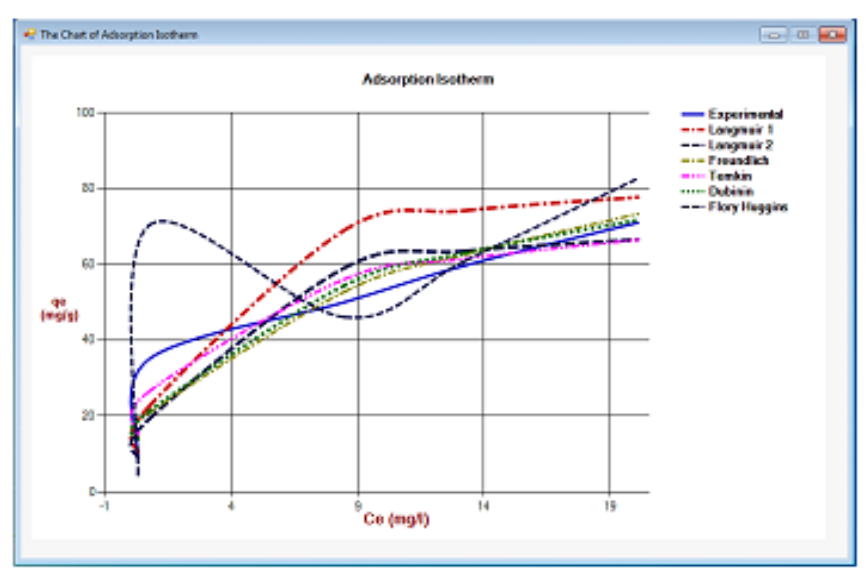

AKU

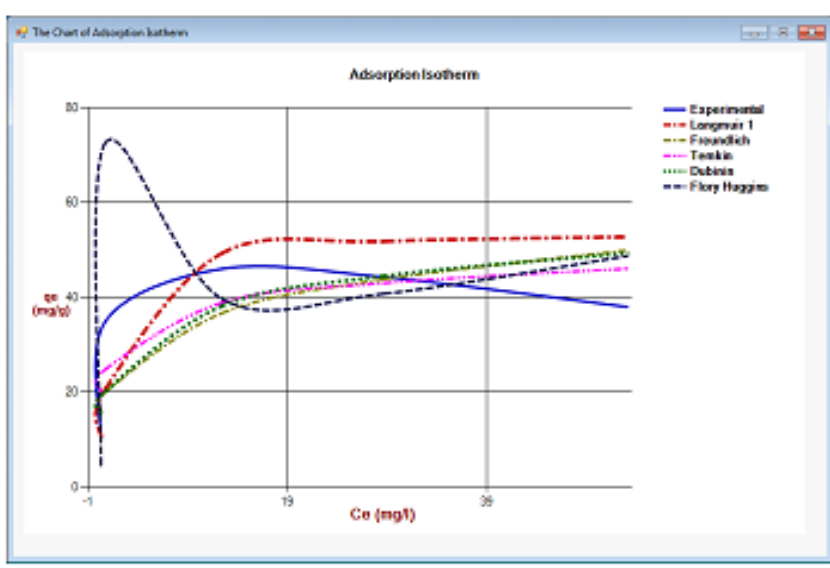

AZM

b) Co 


\section{International Journal of Applied Science and Engineering}

Sorour et al., International Journal of Applied Science and Engineering, 18(5), 2021013

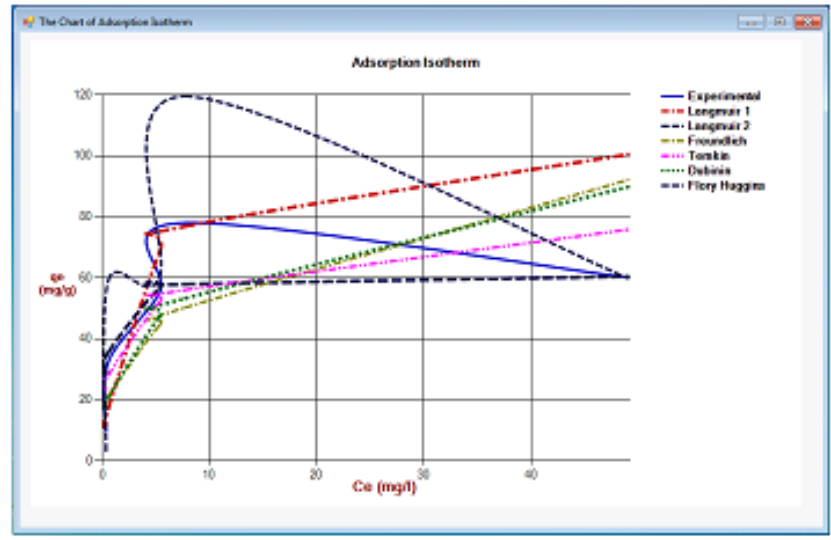

AKU

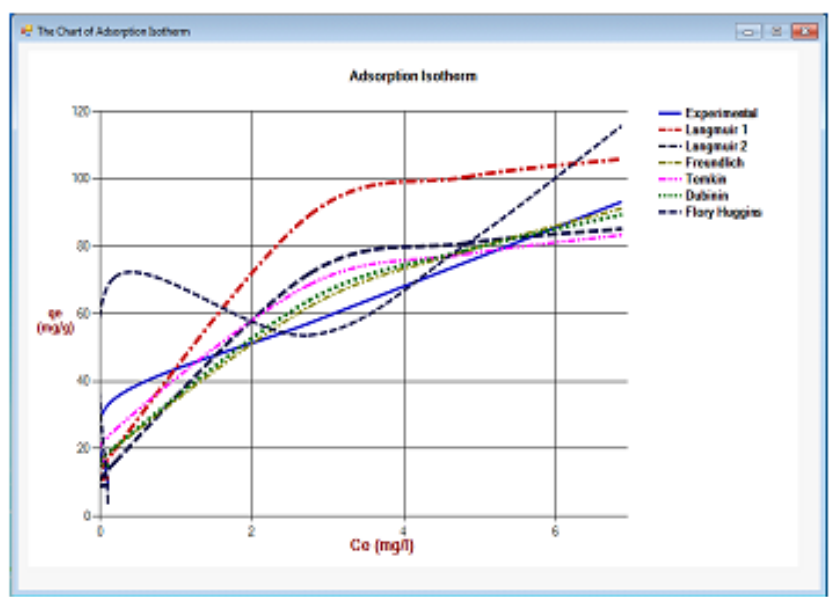

AKU

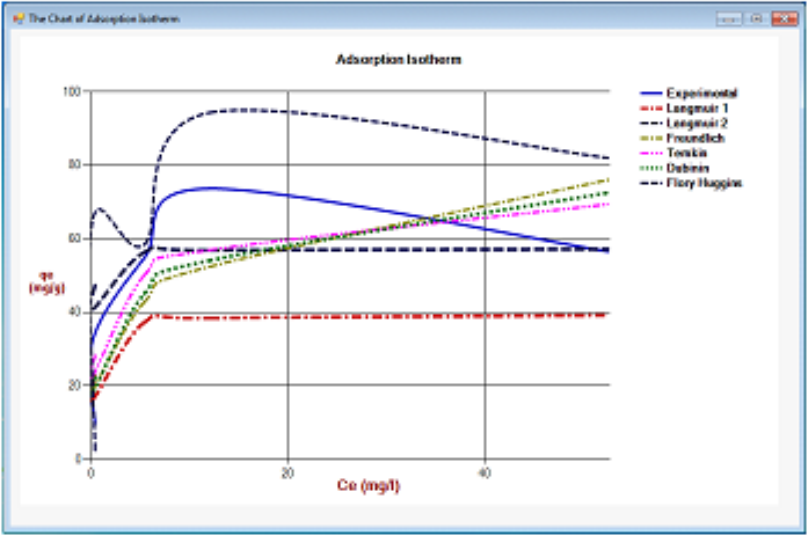

AZM

\section{c) $\mathrm{Ni}$}

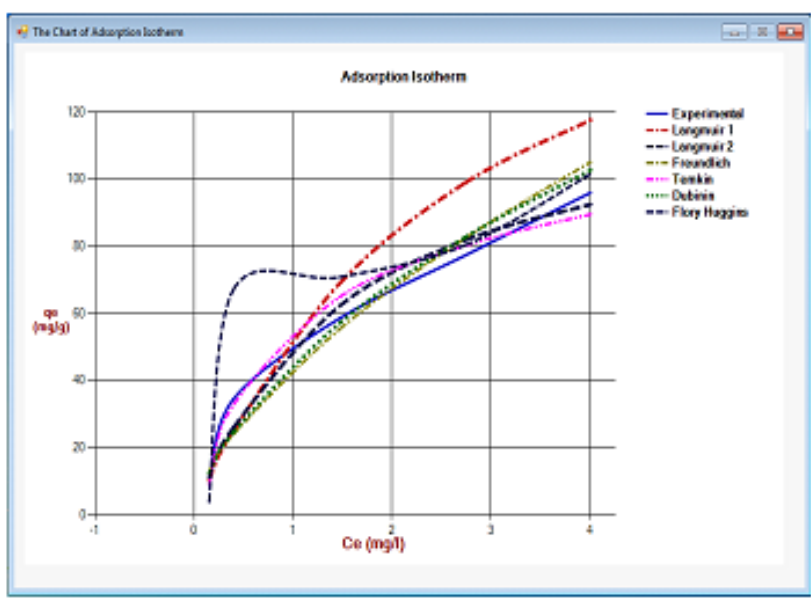

AZM

\section{d) $\mathbf{P b}$}

Fig. 4. Adsorption isotherm plots and isotherms fittings via developed software

Several endeavors for analysis of adsorption data of $\mathrm{Cu}$, $\mathrm{Mn}, \mathrm{Zn}, \mathrm{Cd}$ and $\mathrm{Pb}$ fitted with Langmuir isotherm using different polyacrylate based composites. Examples include the removal of $\mathrm{Pb}, \mathrm{Cd}, \mathrm{Cu}$ and $\mathrm{Zn}$ by sodium polyacrylatehumic acid rectorite composite (Chen et al., 2012), $\mathrm{Cu}, \mathrm{Mn}$, $\mathrm{Zn}$ by kaolinite containing polyacrylic acid-co-acrylamide hydrogels (Atia et al., 2009), $\mathrm{Cu}$ by sodium polyacrylate
(Yu et al., 2015), $\mathrm{Pb}$ by polyacrylic acid bentonite composite (Rafiei et al., 2016), $\mathrm{Pb}$ and $\mathrm{Cd}$ on acrylate/ acrylamide copolymer/GO hydrogel (He et al., 2016b). On the other hand, removal of $\mathrm{Pb}$ by sodium polyacrylate bentonite was investigated by $\mathrm{He}$ et al. and concluded that the results could be fitted best with Freundlich isotherm (He et al., 2016a). 


\section{International Journal of Applied Science and Engineering}

Sorour et al., International Journal of Applied Science and Engineering, 18(5), 2021013

Table 4. Isotherm parameters for heavy metals adsorption using composite hydrogels

\begin{tabular}{|c|c|c|c|c|c|c|c|c|}
\hline \multirow{2}{*}{ Isotherm model } & \multicolumn{2}{|c|}{$\mathrm{Cr}$} & \multicolumn{2}{|c|}{$\mathrm{Co}$} & \multicolumn{2}{|c|}{$\mathrm{Ni}$} & \multicolumn{2}{|c|}{$\mathrm{Pb}$} \\
\hline & $\mathrm{AKU}$ & $\mathrm{AZM}$ & $\mathrm{AKU}$ & AZM & AKU & AZM & $\mathrm{AKU}$ & AZM \\
\hline \multicolumn{9}{|l|}{ Langmuir 1} \\
\hline $\mathrm{R}^{2}$ & 0.921 & 0.973 & 0.941 & 0.897 & 0.801 & 0.173 & 0.88 & 0.974 \\
\hline $\mathrm{q}_{\mathrm{m}}(\mathrm{mg} / \mathrm{g})$ & 169 & 60 & 85.55 & 53.86 & 106.6 & 39.38 & 121.06 & 198.96 \\
\hline $\mathrm{b}(\mathrm{L} / \mathrm{g})$ & 0.074 & 0.121 & 0.492 & 0.868 & 0.33 & 3.291 & 1.017 & 0.361 \\
\hline \multicolumn{9}{|l|}{ Langmuir 2} \\
\hline $\mathrm{R}^{2}$ & 0.967 & 0.97 & 0.972 & 0.992 & 0.996 & 0.994 & 0.946 & 0.96 \\
\hline $\mathrm{q}_{\mathrm{m}}(\mathrm{mg} / \mathrm{g})$ & 84.5 & 37.28 & 73.3 & 38.81 & 60.87 & 57.26 & 97.22 & 128.7 \\
\hline $\mathrm{b}(\mathrm{L} / \mathrm{g})$ & 0.205 & 1.78 & 0.49 & -1.44 & 2.44 & 11.62 & 1.03 & 0.64 \\
\hline \multicolumn{9}{|l|}{ Freundlich } \\
\hline $\mathrm{R}^{2}$ & 0.832 & 0.676 & 0.829 & 0.579 & 0.632 & 0.52 & 0.842 & 0.934 \\
\hline $\mathrm{K}_{\mathrm{F}}(\mathrm{L} / \mathrm{g})$ & 15.14 & 10.96 & 24.43 & 21.5 & 25.58 & 27.91 & 40.58 & 43.23 \\
\hline $\mathrm{n}$ & 1.821 & 2.54 & 2.63 & 4.71 & 3.04 & 3.95 & 2.38 & 1.562 \\
\hline \multicolumn{9}{|l|}{ D-R } \\
\hline $\mathrm{R}^{2}$ & 0.857 & 0.735 & 0.849 & 0.625 & 0.686 & 0.529 & 0.852 & 0.947 \\
\hline $\mathrm{q}_{\mathrm{s}}(\mathrm{mmol} / \mathrm{g})$ & 9.27 & 3.07 & 4.09 & 1.47 & 3.71 & 2.32 & 2.625 & 10.323 \\
\hline $\mathrm{E}(\mathrm{kJ} / \mathrm{mol})$ & 10.18 & 11.4 & 12.71 & 16.42 & 13.174 & 15.46 & 13.45 & 10.912 \\
\hline \multicolumn{9}{|l|}{ Tempkin } \\
\hline $\mathrm{R}^{2}$ & 0.965 & 0.62 & 0.929 & 0.615 & 0.662 & 0.628 & 0.919 & 0.98 \\
\hline $\mathrm{b}_{\mathrm{T}}(\mathrm{kJ} / \mathrm{mol})$ & 0.144 & 0.3 & 0.206 & 0.5 & 0.231 & 0.292 & 0.154 & 0.101 \\
\hline $\mathrm{A}_{\mathrm{T}}(\mathrm{L} / \mathrm{g})$ & 2.69 & 4.76 & 12.39 & 211.41 & 23.81 & 67.65 & 25.62 & 9.53 \\
\hline \multicolumn{9}{|l|}{ Florry Huggins } \\
\hline $\mathrm{R}^{2}$ & 0.49 & 0.84 & 0.695 & 0.788 & 0.639 & 0.501 & 0.602 & 0.598 \\
\hline $\mathrm{K}_{\mathrm{FH}}(\mathrm{L} / \mathrm{mg})$ & 6 & 4.9 & 6.7 & 8.1 & 5.6 & 9.53 & 4.23 & 0.268 \\
\hline$\Delta \mathrm{G}(\mathrm{kJ} / \mathrm{mol})$ & 12.67 & 13.18 & 12.39 & 11.92 & 12.84 & 11.53 & 13.54 & 20.38 \\
\hline
\end{tabular}

\subsection{Adsorption Kinetic Studies}

Adsorption kinetics were studied for the selected adsorbent from $10 \mathrm{~min}$ to $24 \mathrm{~h}$. Results are presented in Fig. 5. Generally, the amount of metals adsorbed increases rapidly in the first hour and continues to increase up to $3 \mathrm{~h}$ for $\mathrm{Pb}$, and $5 \mathrm{~h}$ for $\mathrm{Cr}, \mathrm{Co}$ and $\mathrm{Ni}$, beyond which, there is a minimum increase $(2-5 \%)$ of the adsorption capacity. This trend could be explained by the initial rapid uptake of metal ions and subsequent slow kinetics into the remaining vacant sites where repulsive forces of the initial adsorbed layer tend to minimize the removal of metal ions on the remaining free sites (Green, 2008; Wang and Guo, 2020). Therefore, $3 \mathrm{~h}$ is chosen as the optimum contact time for $\mathrm{Pb}$ and $5 \mathrm{~h}$ for the other ions.

Also, the kinetic data were fitted using Excel software (for linear curve fitting) with Pseudo-first-order, Pseudo second-order and Elovich kinetic models. The values of the calculated kinetic data for AKU are listed in Table 5.
Moreover, AZM values were very close to AKU regarding $\mathrm{Ni}$ and $\mathrm{Pb}$. The Pseudo second-order model is considered more appropriate for depicting the adsorption processes of AKU and AZM. It is worth mention that the Elovich model competes with the Pseudo second-order model only for $\mathrm{Cr}$. AKU adsorbent could be thus considered the optimum composite adsorbent.

Several accomplishments for analysis of adsorption data of different ions fitted with Pseudo second-order kinetics model using different polyacrylate based composites. For example, the removal of $\mathrm{Pb}$ and $\mathrm{Cd}$ by sodium polyacrylatehumic acid rectorite composite (Chen et al., 2012), $\mathrm{Cu}$ by sodium polyacrylate ( $\mathrm{Yu}$ et al., 2015), $\mathrm{Mn}, \mathrm{Cu}, \mathrm{Zn}$ on kaolinite containing polyacrylic acid-co-acrylamide hydrogel (Atia et al., 2009) and $\mathrm{Pb}$ on sodium polyacrylate bentonite (He et al., 2016a). On the other hand, removal of $\mathrm{Pb}$ and on acrylate/ acrylamide copolymer/GO hydrogel fitted with first-order kinetics model (He et al., 2016b). 


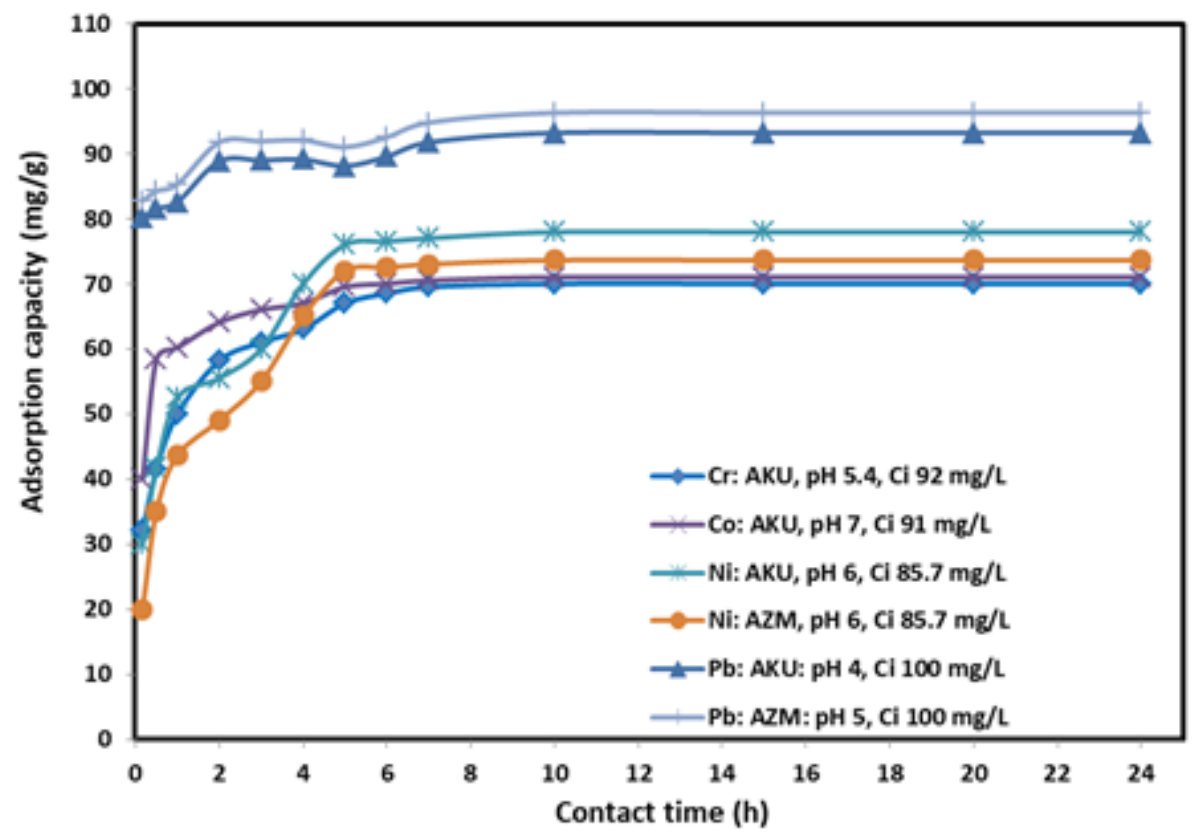

Fig. 5. Effect of contact time on heavy metals adsorption using selected composite hydrogels

Table 5. Kinetic parameters for heavy metals adsorption using optimum AKU composite hydrogels

\begin{tabular}{cccccccc}
\hline Ion & \multicolumn{2}{c}{ Pseudo first order } & \multicolumn{2}{c}{ Pseudo second order } & \multicolumn{3}{c}{ Elovich } \\
\cline { 2 - 7 } & $\begin{array}{c}\mathrm{k}_{1} \\
(1 / \mathrm{min})\end{array}$ & $\mathrm{R}^{2}$ & $\begin{array}{c}\mathrm{k}_{2} \\
(\mathrm{~g} / \mathrm{mg} \cdot \mathrm{min})\end{array}$ & $\mathrm{R}^{2}$ & $\begin{array}{c}\mathrm{b}_{\mathrm{e}} \\
(\mathrm{g} / \mathrm{mg})\end{array}$ & $\begin{array}{c}\mathrm{a}_{\mathrm{e}} \\
(\mathrm{mg} / \mathrm{g} . \mathrm{min})\end{array}$ & $\mathrm{R}^{2}$ \\
\hline $\mathrm{Cr}$ & 0.009 & 0.965 & 0.0006 & 0.998 & 0.0976 & 22.08 & 0.996 \\
$\mathrm{Co}$ & 0.009 & 0.965 & 0.001 & 0.999 & 0.1388 & 377.65 & 0.910 \\
$\mathrm{Ni}$ & 0.01 & 0.952 & 0.0003 & 0.998 & 0.0772 & 11.25 & 0.964 \\
$\mathrm{~Pb}$ & 0.0042 & 0.81 & 0.001926 & 0.999 & 0.313 & & 0.891 \\
\hline
\end{tabular}

\section{CONCLUSION}

This work presented the results of a detailed study of the adsorption process for removal of $\mathrm{Cr}, \mathrm{Co}, \mathrm{Ni}$ and $\mathrm{Pb}$ ions from aqueous solution using developed hydrogel composite adsorbents comprising acrylic acid salts and its blends with Egyptian kaolin or zeolites. Optimum set of adsorption conditions have been developed for the investigated adsorbents including $\mathrm{pH}$, ions concentration and adsorption time. Among the investigated isotherm models, Langmuir isotherm was found appropriate for describing adsorption results on real ground for the studied metal ions. Maximum adsorption capacity using the composite AKU were 97.2, 84.5, 73.3 and $60.9 \mathrm{mg} / \mathrm{g}$ and \% removal $93,92,78$ and $90 \%$ in the order of selectivity $\mathrm{Pb}>\mathrm{Cr}>\mathrm{Co}>\mathrm{Ni}$, respectively. For process design applications, contact time ranging from $3 \mathrm{~h}$ to $5 \mathrm{~h}$ should be adequate for acceptable separation efficiency. As regards to kinetic analysis, second order Pseudo kinetic model proved to be most appropriate for describing time dependence of ions removal. In conclusion, AKU adsorbent could be considered the optimum composite adsorbent.

\section{ACKNOWLEDGEMENT}

This research has been conducted through the project entitled "Fabrication, characterization and performance analysis of a novel low-cost adsorbent for heavy metals removal "within the scope of the National Research Centre eleventh research plan and funding availed through grant no. 11070109.

\section{NOMENCLATURE}

\begin{tabular}{cl}
\hline Abbreviation & \\
\hline $\mathrm{a}_{\mathrm{e}}$ & $\begin{array}{l}\text { initial adsorption rate in Elovich kinetic } \\
\text { model }(\mathrm{mg} / \mathrm{g} \text { min) }\end{array}$ \\
& $\begin{array}{l}\text { Tempkin isotherm equilibrium binding } \\
\text { constant }(\mathrm{L} / \mathrm{g})\end{array}$ \\
$\mathrm{A}_{\mathrm{T}}$ & $\begin{array}{l}\text { Langmuir constant related to the energy } \\
\text { of adsorption }(\mathrm{L} / \mathrm{g}) \\
\mathrm{b}\end{array}$ \\
$\mathrm{b}_{\mathrm{e}}$ & $\begin{array}{l}\text { desorption constant in Elovich kinetic } \\
\text { model }(\mathrm{g} / \mathrm{mg})\end{array}$ \\
& $\begin{array}{l}\text { Tempkin isotherm constant related to } \\
\text { heat of adsorption }(\mathrm{kJ} / \mathrm{mol})\end{array}$ \\
$\mathrm{b}_{\mathrm{T}}$ & Equilibrium ion concentrations $(\mathrm{mg} / \mathrm{L})$ \\
\hline
\end{tabular}


Sorour et al., International Journal of Applied Science and Engineering, 18(5), 2021013

\begin{tabular}{|c|c|}
\hline $\mathrm{C}_{\mathrm{i}}$ & Initial ion concentrations $(\mathrm{mg} / \mathrm{L})$ \\
\hline $\mathrm{E}$ & Energy of adsorption (kJ/mol) \\
\hline $\mathrm{k}_{1}$ & $\begin{array}{l}\text { the rate constant of first order kinetic } \\
\text { model }(1 / \mathrm{min})\end{array}$ \\
\hline $\mathrm{k}_{2}$ & $\begin{array}{l}\text { the second-order sorption rate constant } \\
(\mathrm{g} /(\mathrm{mg} \cdot \mathrm{min}))\end{array}$ \\
\hline $\mathrm{K}_{\mathrm{ad}}$ & $\mathrm{D}-\mathrm{R}$ isotherm constant $\left(\mathrm{mol}^{2} / \mathrm{kJ}^{2}\right)$ \\
\hline $\mathrm{K}_{\mathrm{F}}$ & $\begin{array}{l}\text { Freundlich constant characterizing } \\
\text { adsorption capacity }(\mathrm{L} / \mathrm{g})\end{array}$ \\
\hline $\mathrm{K}_{\mathrm{FH}}$ & Equilibrium constant in Florry model \\
\hline $\mathrm{m}$ & Weight of dry adsorbent ( $\mathrm{g}$ ) \\
\hline $\mathrm{n}$ & $\begin{array}{l}\text { Freundlich constant characterizing } \\
\text { adsorption intensity }\end{array}$ \\
\hline $\mathrm{n}_{\mathrm{FH}}$ & Ions number occupying adsorption sites \\
\hline q & $\begin{array}{l}\text { Amount of metal ions adsorbed in }(\mathrm{mg} / \mathrm{g} \\
\text { of dry adsorbent) }\end{array}$ \\
\hline $\mathrm{q}_{\mathrm{e}}$ & $\begin{array}{l}\text { Equilibrium solid phase concentration } \\
(\mathrm{mg} / \mathrm{g})\end{array}$ \\
\hline $\mathrm{q}_{\mathrm{m}}$ & $\begin{array}{l}\text { Langmuir constant related to the } \\
\text { adsorption capacity }(\mathrm{mg} / \mathrm{g})\end{array}$ \\
\hline $\mathrm{q}_{\mathrm{s}}$ & $\begin{array}{l}\mathrm{D}-\mathrm{R} \text { isotherm theoretical saturation } \\
\text { capacity }(\mathrm{mmol} / \mathrm{g})\end{array}$ \\
\hline$q_{t}$ & $\begin{array}{l}\text { amount of metal ions adsorbed using the } \\
\text { adsorbents }(\mathrm{mg} / \mathrm{g}) \text { at time } \mathrm{t}\end{array}$ \\
\hline $\mathrm{R}$ & The gas constant $\left(8.314 \times 10^{-3} \mathrm{~kJ} / \mathrm{K}\right.$ mol $)$ \\
\hline $\mathrm{T}$ & Absolute temperature $(\mathrm{K})$ \\
\hline $\mathrm{V}$ & Volume of metal ions solution used (L) \\
\hline$\Theta$ & $\begin{array}{l}\text { Degree of surface coverage and is }=(1- \\
\left.\mathrm{C}_{\mathrm{e}} / \mathrm{C}_{\mathrm{i}}\right)\end{array}$ \\
\hline$\varepsilon$ & $\mathrm{D}-\mathrm{R}$ isotherm constant \\
\hline$\Delta \mathrm{G}$ & Gibbs free energy $(\mathrm{kJ} / \mathrm{mol})$ \\
\hline
\end{tabular}

\section{REFERENCES}

Akkaya, R., Ulusoy, U. 2011. Adsorption of lead on to poly (acrylamide-maleic acid)-based hydrogel composites, Hacettepe Journal of Biology and Chemistry, 39, 257264.

Al-Abachi, M.Q. 2013. Evaluation of poly acrylic acid (PAA) hydrogel beads as adsorbent for the removal of lead(II)ion from water, Journal of Al-Nahrain University Science, 16, 30-39.

Atia, A.A., Donia, A.M., Hussin, R.A., Rashad, R.T. 2009. Swelling and metal ion uptake characteristics of kaolinite containing poly [(acrylic acid)-co-acrylamide] hydrogels, Desalination and Water Treatment, 3, 73-82.

Ayawei, N., Ebelegi, A.N., Wankasi, D. 2017. Modelling and interpretation of adsorption isotherms, Journal of Chemistry, 2017, 1-11.

Barakat, M.A. 2011. New trends in removing heavy metals from industrial wastewater, Arabian Journal of Chemistry, 4, 361-377.

Bhatia, M., Rajulapati, S.B., Sonawane, S., Girdhar, A. 2017. Synthesis and implication of novel poly (acrylic acid)/nanosorbent embedded hydrogel composite for lead ion removal, Scientific Reports, 7, 1-16.
Bulut, Y., Akçay, G., Elma, D., Serhatli, I.E. 2009. Synthesis of clay-based superabsorbent composite and its sorption capability, Journal of Hazardous Materials, 171, 717-723.

Chen, F., Ye, W., Tang, Y. 2012. Adsorption of heavy metals by sodium polyacrylate-humic acid-rectorite composite as a novel adsorbent, Advanced Materials Research, 550553, 2428-2435.

Dean, J.G., Bosqui, F.L., Lanouette, K.H. 1972. Removing heavy metals from waste water, Environmental Science and Technology, 6, 518-522.

Djelad, A., Morsli, A., Robitzer, M., Bengueddach, A., Di Renzo, F., Quignard, F. 2016. Sorption of $\mathrm{Cu}$ (II) ions on chitosan-zeolite $\mathrm{X}$ composites: Impact of gelling and drying conditions, Molecules, 21, 1-15.

El-Kamash, A.M., Zaki, A.A., El Geleel, M.A. 2005. Modeling batch kinetics and thermodynamics of zinc and cadmium ions removal from waste solutions using synthetic zeolite A, Journal of Hazardous Materials, 127, 211-220.

Elsayed, M.M. 2019. Hydrogel preparation technologies: Relevance kinetics, thermodynamics and scaling up aspects, Journal of Polymers and the Environment, 27, 871-891.

Emamjomeh, M.M., Sivakumar, M. 2009. Review of pollutants removed by electrocoagulation and electrocoagulation/flotation processes, Journal of Environmental Management, 90, 1663-1679.

Esalah, J.O., Weber, M.E., Vera, J.H. 1999. Removal of lead from aqueous solutions by precipitation with sodium di(n-octyl) phosphinate, Separation and Purification Technology, 18, 25-36.

Foo, K.Y., Hameed, B.H. 2010. Insights into the modeling of adsorption isotherm systems, Chemical Engineering Journal, 156, 2-10.

Ghurye, G., Clifford, D., Tripp, A. 2004. Iron coagulation and direct microfiltration to remove arsenic from groundwater, American Water Works Association, 96, $143-152$.

Gomez-Maldonado, D., Erramuspe, I.B.V., Peresin, M.S. 2019. Natural polymers as alternative adsorbents and treatment agents for water remediation, BioResources, 14, 10093-10160.

Green, D.W. 2008. Perry's chemical engineers' handbook, McGraw-Hill, New York.

Hani, H.A. 2010. Studies on zeolites for heavy metals removal, PhD. Thesis, Faculty of Engineering, Cairo Univeristy, Egypt. http://www.eulc.edu.eg/eulc_v5/ libraries/Start.aspx?ScopeID=1.\&fn=ApplySearch $\& \bar{S}$ ear chIdForm $=\&$ ScopeIDSelect $=1 . \&$ ItemType $=24.2 .5 . \&$ Sea $\operatorname{rchText} 1=$ Heba + hani\&criteria $1=1 . \& o p r 1=$ and $\&$ Search $T$ ext $2=$ Zeolite\&criteria $2=1 . \& o p r 2=$ and $\&$ SearchText $3=\mathrm{He}$ avy + metals \&criteria3 $=1 . \&$ SearchTextFT $=\&$ Generation Term $=\&$ BibID $=\&$ PublishYear $=\&$ OrderKey $=\&$ PageSize $=10$

He, Y., Pei, M., Xue, N., Wang, L., Guo, W. 2016 a. Synthesis of sodium polyacrylate-bentonite using: In situ 
polymerization for $\mathrm{Pb}^{2+}$ removal from aqueous solutions, RSC Advances, 6, 48145-48154.

He, S., Zhang, F., Cheng, S., Wang, W. 2016b. Synthesis of sodium acrylate and acrylamide copolymer/GO hydrogels and their effective adsorption for $\mathrm{Pb}^{2+}$ and $\mathrm{Cd}^{2+}$, ACS Sustainable Chemistry and Engineering, 4, 39483959.

Inagaki, S., Yokoi, T., Kubota, Y., Tatsumi, T. 2007. Unique adsorption properties of organic-inorganic hybrid zeolite IEZ-1 with dimethylsilylene moieties, Chemical Communications, 1, 5188-5190.

Liu, M., Li, W., Rong, J., Zhou, C. 2012. Novel polymer nanocomposite hydrogel with natural clay nanotubes, Colloid and Polymer Science, 290, 895-905.

Liu, Q., Yang, B., Zhang, L., Huang, R. 2015. Adsorptive removal of $\mathrm{Cr}(\mathrm{VI})$ from aqueous solutions by crosslinked chitosan/bentonite composite, Korean Journal of Chemical Engineering, 32, 1314-1322.

Mahmoud, A., Hoadley, A.F.A. 2012. An evaluation of a hybrid ion exchange electrodialysis process in the recovery of heavy metals from simulated dilute industrial wastewater, Water Research, 46, 3364-3376.

Natkański, P., Białas, A., Kuśtrowski, P. 2012. The synthesis of poly (acrylic acid)-bentonite: And polyacrylamidebentonite composites: For adsorption applications, Chemik, 66, 742-749.

Nechifor, G., Pascu, D.E., Neagu, M.P., Traistaru, G.A., Albu, P.C. 2015. Comparative study of temkin and floryhuggins isotherms for adsorption of phosphate anion on membranes, UPB Scientific Bulletin, Series B: Chemistry and Materials Science, 77, 63-72.

Qiu, H., Lv, L., Pan, B.C., Zhang, Q.J., Zhang, W.M., Zhang, Q.X. 2009. Critical review in adsorption kinetic models, Journal of Zhejiang University: Science A, 10, 716-724.

Rafiei, H.R., Shirvani, M., Ogunseitan, O.A. 2016. Removal of lead from aqueous solutions by a poly (acrylic acid)/bentonite nanocomposite, Applied Water Science, 6, 331-338.

Renu, M.A., Singh, K. 2017. Heavy metal removal from wastewater using various adsorbents: A review, Journal of Water Reuse and Desalination, 7, 387-419.

Sezgin, N., Balkaya, N. 2016. Adsorption of heavy metals from industrial wastewater by using polyacrylic acid hydrogel, Desalination and Water Treatment, 57, 24662480 .

Shikuku, V.O., Kowenje, C.O., Kengara, F.O. 2018. Errors in parameters estimation using linearized adsorption isotherms: Sulfadimethoxine adsorption onto kaolinite clay, Chemical Science International Journal, 23, 1-6.

Sorour, M.H., Shaalan, H.F., Hani, H.A., Sayed, E.S. 2018. Batch and dynamic investigations on magnesium separation by ion exchange adsorption: Performance and cost evaluation. 20th International Conference on Energy, Environmental and Chemical Engineering, Dubai, 17021711.

Sorour, M.H., Tewfik, S.R., Abulnour, A.G., Shaalan, H.F., Hani, H.A., Al-Bazedi, G.A. 2020. Development and assessment of adsorptive hydrogel: Process engineering and economic considerations, Engineering Reports, 2, 113.

Wan Ngah, W.S., Teong, L.C., Hanafiah, M.A.K.M. 2011. Adsorption of dyes and heavy metal ions by chitosan composites: A review, Carbohydrate Polymers, 83, 14461456.

Wang, J., Guo, X. 2020. Adsorption kinetic models: Physical meanings, applications, and solving methods, Journal of Hazardous Materials, 390, 122156.

Yakout, S.M., Elsherif, E. 2010. Batch kinetics, isotherm and thermodynamic studies of adsorption of strontium from aqueous solutions onto low cost rice-straw based carbons, Carbon - Science and Technology, 3, 144-153.

Yu, Y., Peng, R., Yang, C., Tang, Y. 2015. Eco-friendly and cost-effective superabsorbent sodium polyacrylate composites for environmental remediation, Journal of Materials Science, 50, 5799-5808.

Yurlova, L., Kryvoruchko, A., Kornilovich, B. 2002. Removal of Ni(II) ions from wastewater by micellarenhanced ultrafiltration, Desalination, 144, 255-260.

Zhang, J., Wang, A. 2015. Polysaccharide-based composite hydrogels for removal of pollutants from water. Advanced separations by specialized sorbents, Chromatographic series, Boca Raton, CRC Press/Taylor $\&$ Francis Group.

Zhao, G., Zhang, H., Fan, Q., Ren, X., Li, J., Chen, Y., Wang, X. 2010. Sorption of copper(II) onto super-adsorbent of bentonite-polyacrylamide composites, Journal of Hazardous Materials, 173, 661-668. 